\title{
FROM PHYSICAL TO ABSTRACT AFFECTEDNESS: THE PREPOSITIONS VRZ AND VĂRHU IN BALKAN SLAVIC
}

\author{
ELENI BUŽAROVSKA \& LILJANA MITKOVSKA \\ Ss. Cyril and Methodius University \& FON University
}

\section{ABSTRACT}

This article investigates the semantics of the Macedonian preposition vrz and its Bulgarian counterpart vărhu from a cognitive perspective. These prepositions represent a rare case of coding the functional meaning of landmark (LM) affectedness, which we understand as a characteristic of a forcedynamic pattern. The article has two related goals: to explain the polysemy of vrz/vărhu by discovering the semantic links between its spatial and non-spatial senses and to filter out the semantic components that vrz/vărhu shares with other related spatial prepositions, such as na 'on', po 'across, over', preku/prez 'over', and nad 'over, above'. The dictionary definitions of both prepositions do not include the affectedness meaning, a fact that obscures the difference in use between vrz/vărhu and the prepositions mentioned above. The authors, on the other hand, show how the spatial domain of $v r z / v a r h u$ is shared by other semantically similar prepositions of superposition and offer an explanation as to why they differ.

An analysis of vrz/vărhu based on the authors' collection of examples helps determine the role of the semantic component of "affectedness" responsible for the special position of this preposition among the prepositions that express superposition. This component is often found with verbs denoting downward movement, such as fall, put, pour, hit, and throw upon, which underscore the affectedness of the LM in conveying the meaning of superposition. This prototype effect is preserved in all spatial extensions, although considerably weakened in the covering sense (Stavete kilim vrz svetol pod. 'Put a rug over a light floor'). It is also pronounced in the non-spatial extensions of $v r z / v a ̆ r h u$ with predicates such as vlijae vrz 'influence', se fokusira vrz 'focus on', prezema kontrola vrz 'take control of' and other similar cases of conceptual transfer from physical to mental/emotional affectedness.

Even though the semantic component of affectedness is also characteristic of the Bulgarian preposition vărhu, the analysis of the Bulgarian examples shows that vărhu, in comparison to $v r z$, does not adhere to this criterion so strictly. This results in a wider distribution of vărhu in both physical and abstract domains. 


\section{[1] INTRODUCTION}

This article investigates the semantics of the Macedonian preposition $v r z$ and its Bulgarian counterpart vărhu from a cognitive perspective. These prepositions represent a rare case of coding the functional meaning of affectedness of the reference object (i.e., landmark, LM) ${ }^{1}$ and thus illustrate the role of a force-dynamic pattern in their semantic structure. Our point here is to show that the functional meaning of affectedness is dominant in the semantics of $v r z / v a ̆ r h u$, especially in Macedonian. We agree with an anonymous reviewer's observation that the functional meaning of affectedness is part of the semantics of almost all prepositions of superposition, but it is our belief that it is often in the background. We wanted to point out that in this preposition affectedness is foregrounded and part of its semantic profile. Therefore, this meaning appears to be decisive in delimiting this preposition (particularly $v r z$ ) from other rival prepositions of superposition. However, it is not equally present in all uses, an issue discussed in Section [2].

The concept of "affectedness" has been used in research on transitivity and argument structure, especially in determining patienthood "usually construed as a persistent change in or impingement of an event participant" (Beavers 2011, $335)$. Similarly, in discussing the semantic macroroles, Van Valin $(2002,8)$ maintains that "[a]ffectedness concerns whether a participant is affected in some way in a state of affairs" and points out that affectedness is a gradable property; that is, "it may range from very great, as with the situations denoted by verbs like crush, kill, and smash, to quite little, as with the states of affairs depicted by verbs like see and like." 2 Drawing on this definition, we use the term "affectedness" for a relation between two objects, but argue that it can also be encoded in the preposition. ${ }^{3}$ We understand "affectedness" as a characteristic of a force-dynamic pattern (Talmy 2000, 413) in which the object (agonist) moves downward due to gravitational force and the LM (antagonist) "holds" it or "stands" in its way; for example, padna vrz 'fall upon', hvărlja se vărhu 'throw oneself on'. The LM becomes affected because it receives force from the object's directed motion during its change of location. ${ }^{4}$ Although this semantic property is related to dynamic verbs of change, we argue that the prepositions $v r z / v a ̆ r h u$, in signaling the endpoint of force transmission, may also convey affectedness. We believe that this preposi-

[1] The term reference object is used in Cognitive Grammar to indicate the less salient element in a figureground organization, interchangeably with the term ground, e.g., (Talmy 2000, 184). The term landmark is also used for this concept, following Langacker (see (Talmy 2000, 253, fn.4); (Langacker 2008, 70)). In this article we mainly adopt the terms landmark (LM) for ground and trajector (TR) for figure.

[2] Beavers $(2011,24)$ also argues in favor of degrees of affectedness encoded in verbs (i.e., predicates), proposing an affectedness hierarchy on a semantic basis.

[3] The term affectedness is also often used in relation to ditransitive constructions involving a dative case (Beavers 2011) and external possession (Janda 1993); (Dąbrowska 1997); (Mitkovska 2007), where the physical and psychological effects on the affected participant merge.

[4] Beavers (2011) notes "As the label 'force recipient' conveys, these participants receive force transmission, which creates the appropriate conditions for change to occur, even if it does not." 
tion has acquired this feature due to its frequent occurrence in this force-dynamic model and, consequently, it may imply affectedness even with an ellipted or "nonforceful" verb. ${ }^{5}$

This pattern is especially productive in the abstract domain, where the affectedness feature is instrumental in the conceptualization of situations of control or influence.

The translational equivalents of $v r z / v a ̆ r h u$ in other Slavic languages are recruited from the domain of superposition and lack this functional meaning. This preposition is based on the Old Slavic noun вьрхъ (Proto-Slavic * vьrх $_{b}$ ) 'top'. In standard Bulgarian it takes the locative form vărhu. In Macedonian the final $x$ was lost and the deictic particle $z$ was added (Skok 1973, 624-625). A similar form, $v r a ̆ z$, is in use in colloquial Bulgarian, and vrz in Serbian dialects in Kosovo (Skok 1973, 624-625). Other prepositions based on the same lexeme are also present in Bulgarian (e.g., svărhu, navărh) but they have limited distribution and are not considered here. In Serbian and Croatian the prepositions navrh 'on top of' and uvrh 'at the top of, above' are in use, but they have no affectedness component.

Adopting a cognitive approach, we base our analysis on the assumption that prepositions represent polysemous units comprising a network of related meanings. We accept the view that the primary senses of prepositions are spatial in nature and they are based in human embodied experience (Johnson 1987). Apart from spatial meanings, prepositions also have functional meanings that can be understood as meaningful consequences of a spatial scene. ${ }^{6}$ The topology of an object (acting as figure; i.e., trajector, TR) in relation to another object (acting as ground; i.e., LM) may create conditions for interaction and mutual influence between them. The functional aspect of a spatial relation gives rise to correlated non-spatial inferences that may develop into abstract meanings. By analyzing the preposition $v r z / v a ̆ r h u$, we would like to shed light on the semantic contribution of the functional element of affectedness to the meaning of this spatial term. How does affectedness relate to the topological element of superposition in the conceptual structure of these prepositions? Does this interrelation depend on context?

[5] Vrz implies the LM's affectedness even if the verb is not forceful (e.g., sedna 'sit down'); this can be illustrated with a contrasting pair of similar situations

(i)

(a) sedna na stolicata 's/he sat on the chair'

(b) ??sedna vrz stolicata 's/he sat upon the chair'

where (b) is rather unusual because the chair is not affected. In a situation in which there is a book on the chair that may be damaged if somebody sits on it, (d) is not only acceptable but even preferable:

(i) (c) sedna na knigata (na stolicata)

(d) sedna vrz knigata na stolicata.

[6] For more discussion on the functional meaning of prepositions see, for instance, (Navarro i Ferrando 2001, 61), (Tyler \& Evans 2003, 26-27), (Šarić 2008, 18), (Coventry 1998, 256), and (Coventry 2003, 261). 
We draw on Coventry \& Garrod's (2004) view that geometric and functional components interact to different degrees in different discourse contexts. They argue that, in the case of the spatial term in, a functional component of location control interacts with a geometric component of enclosure. These components "support" each other to different degrees when one of them is "weak" (Coventry \& Garrod $2004,53)$. We assume that there is a similar correlation between affectedness and superposition in the prototypical meanings of $v r z / v a ̆ r h u$.

Discourse factors should also be taken into consideration in the interpretation of $v r z / v a ̆ r h u$. Although we are aware that contextual variability influences the interpretation of the prepositions analyzed, we assume that a common topological structure-an abstract schema-unites all the meanings in different contexts (Taylor 2002, 519-520). However, the functional component in the semantics of the preposition $v r z / v a ̆ r h u$ seems to be decisive in delimitating them from other superpositional prepositions that share a similar topological meaning. Coventry's position $(2003,266-267)$ that prepositions may be differently affected by pragmatic and semantic information and that in some contexts functional relations dominate ${ }^{7}$ is supported by the behavior of the prepositions vrz and vărhu. Various contextual factors either highlight or background a particular geometric or functional feature in their semantic structure. This in turn causes widening or narrowing of their semantic scope, which results in different contextual applicability of these prepositions.

This article discusses the polysemy of the preposition $v r z$ in Macedonian and compares it with the Bulgarian preposition vărhu in order to establish the functional zone of these similar prepositions. Although the two languages use the same preposition as translational equivalents, the distribution and frequency of uses do not overlap because "the boundaries between the contrasting categories often differ" (Šarić 2008, 229). In addition, we isolate the semantic components that $v r z / v a ̆ r h u$ shares with similar prepositions of superposition-na 'on', po 'across, over', preku/prez 'over', and nad 'above/over'-and determine the features that distinguish $v r z / v a ̆ r h u$ from them.

The Macedonian dictionaries list several senses of $v r z$, which can be divided into spatial and non-spatial. The first meaning listed usually describes the spatial relation involving position or movement of an object on top of or along/over the surface of something (Koneski 2003, 309-310), or an object on or over/along the upper surface of something (Murgoski 2005, 96). Such definitions indicate the semantic affinity of $v r z$ with the prepositions na, po, and nad. The second sense listed is non-spatial, vaguely defined as "object of the activity" (Koneski 2003, 309-310)

[7] Coventry $(2003,267)$ states that "it is possible to create a context in which functional relations dominate. Therefore, contrary to the commonly held view that there is a single system underlying spatial language and spatial representation that is geometric in nature, the evidence points to the need for the instantiation of multiple systems of representation that are integrated 'in line."' 
or an activity producing some effect (Murgoski 2005, 96). There is also mention of the sense "piling up objects of equal type" and the set phrase vrz osnova na "on the basis of'. Similar explanations are given for the Bulgarian counterpart. According to Bulgarian dictionaries (Andrejčin et al. 1963, 99) and electronic dictionaries, ${ }^{8}$ the spatial meanings of vărhu correspond to those of vrz: superposition and movement to the "object of activity." However, in both meanings, no distinction is made between physical and abstract senses, although the examples presented clearly illustrate the difference.

Our analysis is based on more than 350 examples collected from authentic sources, electronic as well as printed (both Macedonian and Bulgarian). ${ }^{9}$ In contrast to traditional lexicographic descriptions of the meanings of $v r z / v a ̆ r h u$, the cognitive approach allows us not only to determine the spatial senses, but also to recognize the functional ones. In Section [2] we describe how they arise from the spatial relation of $v r z / v a ̆ r h u$ and further develop into abstract senses, thus forming a network of related senses. The proposed network shows the regularity of semantic change, whereas the comparison of $v r z / v a ̆ r h u$ with similar prepositions in each use helps establish the functional scope of the prepositions analyzed. In Section [3] the relation between the rival prepositions coding superposition is summarized and Section [4] offers some concluding remarks.

\section{[2] SPATIAL SENSES OF VRZ/VĂRHU AND ITS RELATED NON-SPATIAL SENSES}

\section{[2.1] Vertical static spatial meaning: prominence}

In the vertical static spatial meaning, vrz/vărhu indicates that a static object is positioned on the upper surface of the LM. Although this meaning is infrequent, especially in $v r z$, the lexical semantics of 'top' seems to be the source for the other two senses. We presume that in the creation of a LM's prototypical meaning of affectedness the shape of the LM plays an important role: it is convex with a protruding upper part (1). However, with the extension of its use onto other LMs, the protruding requirement becomes neutralized. In such uses, vrz is very similar to $n a$ or nad and hence often mutually interchangeable. Yet they all differ with respect to their functional meaning: unlike $n a$, vrz implies that the TR dominates the scene (1) and/or affects the LM in some way (2). The affectedness component is rather low, especially in Bulgarian vărhu (3), which is more frequently used in this meaning than Macedonian vrz. Thus, the reason why many Bulgarian exam-

[8] http://rechnik.info; http://www.t-rechnik.info/search.php?search

[9] Because there is no comprehensive electronic corpus of Macedonian, we collected examples from various sources. The sources include internet blogs and forums, electronic versions of newspapers, magazines, books, and printed sources. The printed sources consist of Macedonian and Bulgarian short stories: Dragi Mihajlovski, Peperutkarot (Skopje: Kaprikornus, 2010); Rumena Bužarovska, Osmica (Skopje: Blesok, 2010); Dimităr Tolev, Razkazi, povesti (Sofia: Narodna kultura, 1967); Kristina Dimitrova, Ljubov i smrt pod krivite kruši (Sofia: Obsidijan, 2004). The examples used in the article were translated by the authors. Macedonian examples are marked with (M) and Bulgarian with (B). 
ples with vărhu cannot be translated with vrz is the absence of affectedness in a given situation. For instance, the translation equivalents of the movie title Bird on a Wire are Ptica vărhu žica in Bulgarian and Ptica na žica in Macedonian. The alternative variant with $v r z$ would imply that the bird's pressure on the wire causes a certain sagging.

(1) a. Štipskite vernici ne sakaat antena vrz kambanarijata. (M) 'The faithful in Štip don't want an antenna on top of the bell tower.' b. Vašiot ured ne mora da stoi vrz televizor. (M) 'Your gadget doesn't have to be on the TV set.'

(2) Luǵeto pominuvaat, se zagleduvaat vo čudnata gletka, a drvoto ušte stoi vrz avtomobilot.

'People pass by, stare at this strange scene, but the tree is still on top of the car.'

(3) Žiteli na Sozopol skočiha sreštu stroeža na moderen hotel vărhu skalite. (B)

'The residents of Sozopol protested against the construction of a modern hotel on the cliff top.'

\section{[2.2] Physical support: pressure}

The meaning of physical support hinges on the features of contact and dimensionality. This relation profiles a voluminous TR positioned on a LM as a supporting ground, basically similar to the relation expressed by the preposition na. However, unlike $n a$, the preposition vrz/vărhu suggests that LM supports the TR despite the latter's considerable weight. In fact, the difference between these two prepositions is not topological, but affective: the preposition na states only the position, while vrz/vărhu adds an expressive dimension to the relation. In the following examples, vrz/vărhu can be replaced by na without any change in meaning, but vrz/vărhu emphasizes the TR's size and/or pressure.

(4) Kupolata se potpira vrz/na četiri stolba. (M)

'The dome rests on four columns.'

(5) Toj e bleden, no spokoen, podpira se s dvete si răce vărhu sabljata. (B)

'He is pale, but calm, leans with both hands on his saber.'

\section{[2.3] Abstract meaning: psychological/mental support, base}

The abstract meaning of support in Macedonian $v r z$ is a product of metaphorical transfer from the relation of physical support into the domain of human relations or reasoning. Thus, $v r z$ denotes some kind of reinforcement that comes from the reference base (6). Associative relations can also be established between physical entities, as well as people (7). 
(6) Državata se potpira vrz silna populistička propaganda. (M)

'The country relies on strong populist propaganda.'

(7) Podatocite vrz koi se zasnova procenata za rizikot (M)

'Data on which the estimation of risk relies'

Bulgarian vărhu seems to be much less frequent in this meaning, although we encounter examples with the verb opira se 'is based' (8).

(8) Opirat se vărhu indianski duhovni tradicii na Kasteneda, Redfijld i dr. (B) 'They rely on the Indian spiritual traditions of Castaneda, Redfield, etc.'

The preposition $n a$ is equally possible in expressing such abstract relations (9) both in Macedonian and Bulgarian, and it seems to be more frequently used because of its neutral tone. Due to its expressivity, the preposition vrz/vărhu may serve stylistic purposes.

(9) Estonija ḱe se potpira na/vrz NATO za da se zaštiti od neprijatelot. (M)

'Estonia will rely on NATO to protect itself from an enemy.'

More detailed investigation into the syntactic and semantic conditions for occurrence of the two prepositions might shed some light on the divergent tendencies in their behavior. Apart from the expressive nature of $v r z$ already mentioned, the polyfunctionality of $n a$ may also be a relevant factor for the choice of $v r z$.

The preposition na cannot replace vrz in the set phrase vrz osnova na 'on the basis of' based on the metaphor of support. This complex preposition is quite common in administrative registers: vrz osnova na clen 75 'on the basis of Article 75', vrz osnova na izjavata na 'on the basis of the statement of. Bulgarian uses the preposition văz in the same construction văz osnova na 'on the basis of', which is commonly used in administrative styles (Pašov 2002, 247).

\section{[2.4] Force-dynamic meaning: motion resulting in affectedness (physical impact)}

The vertical dynamic spatial sense of vrz/vărhu seems to be the most frequent in both languages. The preposition evokes an image of an object (TR) coming down on another object (LM) with speed and force, ending up located with its full lower surface on the upper surface of the LM (10) and (11). The role of force is crucial for this configuration, as well as for a number of other conceptualizations. ${ }^{10}$ This force-dynamic pattern gives rise to a functional meaning of affectedness, which arises in combination with verbs of forceful physical motion. It is precisely because of the frequent occurrence of $v r z / v a ̆ r h u$ with such verbs that the meaning of

[10] Johnson $(1987,42)$ notes that: "Because force is everywhere, we tend to take it for granted and to overlook the nature of its operation. We easily forget that our bodies are clusters of forces and that every event of which we are part consists, minimally, of forces in interaction." 
"affectedness" becomes associated with this preposition. ${ }^{11}$ The use of the preposition $v r z / v a ̆ r h u$ automatically presupposes that the TR somehow affects the LM by its action.

(10) Nepoznati napaǵači včera frlile molotov koktel vrz turskiot konzulat. (M) 'Unknown assailants threw a Molotov cocktail at the Turkish consulate yesterday.'

(11) Kola padna vărhu kăšta pălna s deca. (B)

'The car fell on a house full of children.'

The affectedness effect is often reinforced by some context elements that emphasize the weight of the TR (12) or explicitly state its consequences on the TR (13). These elements are, however, only additional contextual support and do not determine the meaning of the preposition. Thus, in (12), if the phrase težok dožd 'heavy rain' is replaced by siten dožd 'light rain', the affectedness meaning will not be eliminated. ${ }^{12}$

(12) Težok dožd paǵa vrz moeto telo. (M)

'Heavy rain falls on my body.'

(13) Težok kufer paǵa vrz glavata na dedoto a patnicite konstatiraat deka e mrtov. (M)

'A heavy suitcase falls on the old man's head and the passengers determine that he is dead.'

The TR may be a liquid or other type of material that affects the LM with its physical or chemical properties: in (14) coffee damages the communications system, and in (15) light dispels darkness.

(14) Pilotot go isturil svoeto kafe vrz opremeta za komunikacija na avionot. (M)

'The pilot spilled his coffee over the communications system on the dashboard of the aircraft.'

(15) Svetlinata se izsipva vărhu platnoto za da progoni mraka v očite. (B) 'The light falls on the canvas in order to dispel darkness.'

This functional meaning of affectedness sets vrz/vărhu apart from the comparable spatial preposition na 'on', which also codes physical contact, but profiles support rather than pressure. In our collected examples, vrz/vărhu predominantly collocates with verbs that code forceful downward movement (paǵa 'fall', isturi 'pour', frla 'throw', udira 'hit') as in (16), but there are also verbs with no special force

[11] This conclusion dovetails with an anonymous reviewer's observation.

[12] We thank an anonymous reviewer for bringing up this point. 
implication (stavi 'put', se roni 'crumble'). In (17a) the passersby are affected even though the verb itself does not imply force; in (17b) it is the preposition vrz that produces such an effect, not the neutral verb stavi 'put'. This suggests that the preposition itself can create the affectedness scenario.

(16) Zaradi silnija vjatăr v stolicata dărvo padna vărhu mlad măž dokato toj izlizal ot ... (B)

'Due to strong wind in the capital, a tree fell on a young man when he was coming out...'

(17) a. Fasadite se lupat ... i se ronat vrz glavite na minuvačite. (M)

'The façades of the houses crack and fall on the heads of the passersby.'

b. Ne ja stavaj kutijata vrz masata. Ḱe ja oštetiš. (M)

'Don't put the box on the table. You'll damage it.'

This implication of affectedness is preserved even in static conceptualization, where the weight of the TR is perceived as exerting some considerable effect on the LM (18).

(18) Tumorot pritiska vrz nervite. (M)

'The tumor presses on the nerves.'

\section{[2.5] Abstract meaning: affectedness through physical impact}

The "impact" meaning that codes "placing TR on top of the LM and in the process considerably affecting it" is directly related to the meaning of physical and psychological affectedness of the LM. In such relations, the contact feature is not central, but only marginally implied. The TR makes an intended impact on the LM by some forceful movement (puka 'shoot') or forceful activity (se izživuva 'molest'), as in (19). The effects on the TR may be highlighted even if the action is not physically forceful (20).

(19) Obvinetiot se tovari deka seksualno se izživuval vrz deteto. (M)

'The accused is charged with sexually molesting the child.'

(20) Ne kupuvam stoki testvani vărhu životni. (B)

'I don't buy goods tested on animals.'

The affectedness meaning of $v r z / v a ̆ r h u$ is often expressed in collocations with nominalizations (napad 'attack', atentat 'assassination', vandalizam 'vandalism', nasilstvo 'violence') or periphrastic predicates in which the activity is coded by an abstract noun or nominalization in a construction with a light verb " $\mathrm{V} \mathrm{N} v \mathrm{rz} / v a \mathrm{rhhu}$ N" (vrši napad 'attack', vrši operacija 'operate on', vrši intervencija 'intervene', primenuva nasilstvo 'apply violence'). 
(21) Londonskata policija primeni nasilstvo vrz demostranti (M) 'London police applied force against protesters.'

(22) Teroristite izvăršvat genocid vărhu deca v Holms (B)

'Terrorists are carrying out genocide on children in Holms.'

Following the same pattern, vrz/vărhu builds constructions with nomina agentis such as napaǵač 'attacker', vladetel 'ruler', and so on. These nominals absorb the first argument of the nominalized predication, rendering the type of activity through the semantics of the agent. Thus in (23) the verbal nominalizations that appear as TRs in the relation expressed by the preposition in fact represent a metonymy for the activity: napaǵačot A vrz B 'the attacker A upon B' < 'A attacks B'. In Bulgarian the preposition nad is preferred to vărhu in similar contexts, as in (24).

(23) Napaǵačot vrz komplekstot na ON e uapsen. (M)

'The attacker on the UN headquarters has been arrested.'

(24) Razkriha napadatel nad ženi. (B)

'The attacker on women has been found.'

\section{[2.6] Abstract affectedness and influence/control}

Expressions coding physical affectedness (e.g., udri vrz, pritiska vrz, napaǵa vrz) in both languages can be extended to relations with abstract LMs, thus giving rise to abstract affectedness (25) and (26).

(25) Poskapiot benzin pritiska vrz cenite na transportnite uslugi. (M)

'Expensive gasoline puts pressure on the price of transportation.'

(26) Vsičkite igri ... s cenite na brašnoto, reflektiraha lošo vărhu hljaba. (B)

'The manipulations of flour prices have had a negative impact on bread.'

If the LM is personal or metonymically points to people, as in examples (27) and (28), the relation coded by the preposition $v r z / v a ̆ r h u$ is liable to further abstraction. The impact of the TR is viewed as producing psychological effects on the LM (29).

(27) Korumpiranite sindikati težat vrz grbot na rabotnicite. (M) 'Corrupt trade unions weigh on the backs of the workers.'

(28) Dolgovite pritiskaat vrz firmite. (M)

'Debts put pressure on firms.'

(29) Spisokăt na žertvite koito težat vărhu săvestta na carja, ne svăršava tuk. (B)

'The list of victims weighing on the czar's conscience does not end here.' 
The functional meaning of affectedness expressed by $v r z / v a ̆ r h u$ extends into the abstract domain to meanings of the TR's exertion of influence and/or control on the LM, where the physical contact component is irrelevant, cf. examples (30) and (31). In such relations, an abstract or physical TR affects the LM with some inherent property or by directing energy towards the LM.

(30) Beliot leb štetno deluva vrz zdravjeto na luǵeto. (M) 'White bread has negative effects on people's health.'

(31) Depresijata na majkata vlijae vărhu mozăka na deteto. (B)

'A mother's depressive state has an effect on her child's brain.'

The same verbs, periphrastic predicates and nominals that appear in physical relations contexts (paǵa 'fall', frla 'throw', istura 'spill') combine with vrz to code abstract relations. To convey psychological effects of control exertion, vrz co-occurs in various constructions: 1 ) with abstract nouns (danok 'tax', embargo 'embargo', veto 'veto', pravo 'right', sopstvenost 'ownership'); 2) with resultative or event nominals, (vlijanie 'influence', vnimanie 'attention', koncentriranje 'concentration', fokusiranje 'focusing', pogled 'glance/view', dejstvo 'effect', udar 'attack', pritisok 'pressure'), and 3) in periphrastic predicates (vrši pritisok vrz naselenieto 'puts pressure on citizens', vrši kontrola vrz proizvodstvoto 'conducts control over the production', vrši vlijanie vrz glasačite 'exerts influence over voters', frli pogled vrz knigata 'cast a glance at the book'), which is a more common pattern than with a single verb. ${ }^{13}$

When the same meaning is not rendered by a periphrastic predicate but by a single verb, three types of complementation patterns are possible: a) some verbs require direct objects (vrši kontrola vrz proizvodstvoto $>$ go kontrolira proizvodstvoto 'maintains control over the production' > 'controls the production'), b) some require prepositional objects (vrši vlijanie vrz glasačite $>$ vlijae vrz glasačite 'exerts influence over voters' > 'influences voters'), and c) some verbs allow both (go pritiska naselenieto/pritiska vrz naselenieto 'puts pressure on the citizens/pressure the citizens'), the difference being in the degree of the LM's affectedness. However, in a number of cases in both languages the periphrastic predicate cannot be replaced by a single verb: frla senka/damka 'casts a shadow', prezema kontrola 'takes control', ima efekti 'has effects', ima/dava pravo 'has/gives the right', etc.), exemplified in (32) and (33).

(32) NATO ja prezede kontrolata vrz voenata akcija protiv Libija. (M) 'NATO has assumed control over the military operation in Libya.'

[13] The same types of constructions occur in Bulgarian with vărhu: hvărlja petno vărhu cjalata bolnica 'cast a shadow over the whole hospital', ima efekti vărhu čoveškija organizăm 'has effects on human body'. 
(33) Edin otdelen incident ne može da hvărli sjanka vărhu tradicionno dobrite otnošenija. (B)

'A single incident cannot cast a shadow over traditionally good relations.'

Regular co-occurrence of certain light verbs with $v r z / v a ̆ r h u$ has resulted in their idiomatization. A typical example is the verb paǵa 'fall' in examples (34) and (35).

(34) Odgovornosta paǵa vrz organizatorot na demonstraciite. (M)

'The responsibility falls on the organizer of the demonstrations.'

(35) Iskame vărhu našeto ime kato partija da ne pada petănce. (B)

'We, as a party, demand that no blemish should be cast upon our name.'

\section{[2.7] Abstract meaning: attention focusing and activity absorption}

The semantic component odozgora 'on top of' represents a base for the rise of the functional meaning of mental focusing. With certain predicates, vrz/vărhu denotes that a human TR directs attention towards an LM engaged in some mental activity. Usually $v r z / v a ̆ r h u$ combines with the verb raboti 'work', cf. examples (36) and (37), but other verbs are also encountered (e.g., se zamisli vrz problemot 'reflected on the problem', se fokusira vrz ekonomijata 'to focus on the economy').

(36) Rabotam vrz najnoviot poetski rakopis. (M)

'I am working on my latest poetry manuscript.'

(37) Rabotja vărhu nova kniga. (B)

'I am working on a new book.'

The agent's focus on the object is also expressed with the prepositions na and nad. The former is more common in both languages, whereas the latter is characteristic for Bulgarian, but less frequent in Macedonian. ${ }^{14}$ Even though there are contexts in which all three prepositions are interchangeable, each one has a specific, often contextual, nuance that is difficult to capture. The reason for their specialized application may lie in the conventionalization of collocational combinations.

Topic/theme (in Bulgarian only)

Additionally, the Bulgarian preposition vărhu occurs in the abstract meaning of "aboutness" or "topic/theme" (38), whereas its Macedonian counterpart vrz has not developed such a use. Macedonian employs the preposition $z a$ 'for, about' to express this relation. Such uses involve predicates of speech and cognition, in

[14] Cf. (Mitkovska \& Bužarovska 2012, 130-131) on the use of the preposition nad in South Slavic languages and Tyler and Evans's analysis of over (Tyler \& Evans 2001). 
whih the preposition marks the topic of conversation or thought and could be paraphrased as 'relating to, with reference to, with regard to'.

(38) Tekstăt spodelja razmisli vărhu neobičajnata situacija. (B)

'The text conveys thoughts about the unusual situation.'

\section{[2.8] Competition between the preposition vrz/vărhu and na}

In the meaning of physical affectedness, the preposition $v r z / v a ̆ r h u$ competes with $n a$ 'on'. Because both imply that the TR comes to or is positioned in contact with the LM (which usually supports the TR on the upper surface), they are interchangeable in many contexts (39). However, the main feature of on is control: the LM controls the location of the TR in the horizontal or vertical axis of the LM (Beavers 2002), whereas vrz/vărhu highlights the effect of the attachment of the TR with the LM. ${ }^{15}$ The examples analyzed suggest that the implication of affectedness is inherent in $v r z$ whereas $n a$ is neutral in this respect. This explains why in some contexts the use of $n a$ is either not preferred or marginal (40).

(39) Nepoznati napaǵači včera frlile molotov koktel vrz/na turskiot konzulat. (M)

'Unknown assailants yesterday threw a Molotov cocktail at the Turkish consulate.'

(40) Most star 150 godini padna vrz/?na voz što pominuval pod nego i ubi 33 patnici. (M)

'A 150-year-old bridge collapsed on a train passing under it and killed 33 passengers.'

The preposition $v r z / v a ̆ r h u$ is mainly used with predicates (or their nominalizations), signaling that the second participant is strongly affected by the activity; namely, it emphasizes the patienthood of the second participant, whereas na invites no such inference. This difference is equally maintained in abstract relations, although not as regularly because the choice depends more heavily on the speaker/writer's construal of the relation (compare examples (30)-(31) with examples (41)-(42)). In such cases, the two prepositions are used for stylistic variation.

(41) Slabeenjeto može štetno da deluva vrz zdravjeto. (M)

'Slimming down can be harmful to one's health.'

(42) Esenta naistina vlijae na nastroenieto. (B)

'Autumn really can affect one's mood.'

[15] According to Brala (2005), the domain of suPERPOSITION lexicalized in Croatian by nad, iznad, preko, and $n a$ is split into two subordinate levels: +/- ATтACHмENT (na vs. nad, iznad, preko). 
Another reason for choosing $v r z$ over $n a$ is to avoid the ambiguity that the multifunctional preposition na could create. Because $n a$ is used for both agentive and patientive participants of a nominalized predication, it may be unclear whether the object of the preposition refers to the initiator or the undergoer, whereas vrz clearly points to the patient. Thus, the expression pritisok na vladata 'pressure of/on the government' may be interpreted as 'pressure of the government' or 'pressure on the government' but the use of vrz in pritisok vrz vladata clarifies that the government is the affected entity.

Furthermore, the preposition na is used for marking both possession and indirect object (experiencer or recipient), causing ambiguity in certain contexts. By using $v r z$, the speaker/writer clearly points at the experiencer (43). In addition, $v r z$, in contrast to na, possesses certain expressivity and thus is more common in headlines as a stylistic attention-capturing device, whereas the body text contains $n a$, as in the following example. ${ }^{16}$

(43) Doždot i gradot napravija šteti vrz posevite. (headline)

Spored informaciite od farmerite gradot napravi šteti na žitnite i gradinarski kulturi. (M)

'Rain and hail cause damage to crops.

According to information from farmers, the hailstorm caused damage to crops in fields and gardens.'

In Bulgarian, the obsolete preposition vrăz is found instead of vărhu in stylistically marked contexts. ${ }^{17}$ In newspaper headlines (44) and literary prose (45), it conveys a greater degree of expressivity.

(44) Džip parkira vrăz stăpalata na Etnografskija muzej. (B)

'The jeep parked at the entry to the Ethnographic Museum.'

(45) Snegăt turi smălčana pokrivka vrăz vsičko. (B)

'The snow spread a silent cover over everything.'

\section{[2.9] Horizontal spatial meaning: spreading over a surface, covering}

The third spatial meaning of $v r z / v a ̆ r h u$ presupposes contact of the TR with a broader surface of the LM, usually the entire upper surface, which gives rise to the functional meaning of partial or full covering; examples (46) and (47). In (46), the print covers part of the shirt; it also indicates that the TR and LM are not necessarily positioned on the vertical axis. Actually, here the location of the TR on the horizontal axis is controlled by a planar LM.

[16] This is perhaps one of the reasons why we encounter vrz in poetry more often than in other genres.

[17] We would like to thank Ivelina Tchizmarova for this observation and for providing exhaustive interpretation of the examples with vrăz. 
(46) Pečatenje vrz maici i tekstil. (M)

'Printing on T-shirts and fabric.'

(47) Razlivam voda vărhu masata. (B)

'I spill water over the table.'

Given that the TR is not concentrated on a limited spot of the LM, it is not viewed as producing a considerable impact. Therefore the affectedness component is negligible or totally absent. It seems that the presence of the feature of dimensionality (or rather planarity) of the "controller" LM (Brala 2005) suspends the affectedness effect of the TR's superpositional attachment onto the LM. The degree of affectedness also depends on the physical makeup of the object; for example, liquids versus solid objects, as in (47).

Bulgarian vărhu is more often encountered in this meaning than vrz in Macedonian; the latter has a limited distribution, probably because it suggests verticality and hence the affectedness effect is more pronounced. Quite often in such contexts the Macedonian equivalent of $v a ̆ r h u$ is not $v r z$, but na or po, as in examples (48) and (49).

(48) "Bălgarija vărhu kulturnata karta na sveta" e mnogo ljubopitna kniga. $(=n a)(\mathrm{B})$

'Bulgaria on the Cultural Map of the World is a very curious book.'
Arabski tatuirovki vărhu telata na zvezdi. $(=p o)(B)$
'Arabic tattoos all over the bodies of pop stars.'

In contexts in which both prepositions are possible in the two languages, vărhu prevails in Bulgarian, whereas na is more common in Macedonian, although vrz is also an option, cf. examples (50) and (51).

(50) a. Nanesete smesata vărhu liceto i sled 20 minuti izmijte. (B)

b. Nanesete ja smesata na liceto i držete ja 20 minuti. (M)

'Apply the mixture to your face and let it sit for 20 minutes.'

(51) a. Evropejskata komisija odobri novi 14 predupreditelni nadpisa, koito šte mogat da bădat otpečatvani vărhu kutiite s cigari. (B)

'The European Commission has approved fourteen new graphic warnings that may be printed on cigarette packs.'

b. Spored sudijata, grafičkite predupreduvanja za štetnosta od pušenjeto vrz kutiite so cigari i vrz reklamnite materijali gi prekršuvaat osnovnite slobodi. (M)

'According to the judge, the graphic warnings concerning the hazards of smoking on cigarette packs and on advertising materials violate basic rights.' 
TABLE 1: Google search results for vărhu/vrz and $n a$ in contexts of spreading over a surface

\begin{tabular}{|c|c|c|}
\hline & Bulgarian & Macedonian \\
\hline & (nadpisi) vărhu cigareni paketi & (natpisi) vrz kutii so cigari \\
\hline & $-13,900$ hits & -4 hits \\
\hline & \multicolumn{2}{|c|}{ '(labels) on cigarette packs' } \\
\hline & (nadpisi) $n a$ cigareni paketi & (natpisi) na kutii so cigari \\
\hline & -9 hits & \\
\hline & \multicolumn{2}{|c|}{ '(labels) on cigarette packs' } \\
\hline \multirow{7}{*}{ Ratio } & vărhu to na $99.94 \%$ to $0.06 \%$ & vrz to na $0.04 \%$ to $99.96 \%$ \\
\hline & Nanesete smesata vărhu liceto & Nanesete ja smesata $v r z$ liceto \\
\hline & $-45,700$ hits & -1 hit \\
\hline & \multicolumn{2}{|c|}{ 'Apply the mixture [all] over your face.' } \\
\hline & Nanesete smesata $n a$ liceto & Nanesete ja smesata $n a$ liceto \\
\hline & $-15,700$ hits & $-1,790$ hits \\
\hline & \multicolumn{2}{|c|}{ 'Apply the mixture to/on your face.' } \\
\hline Ratio & vărhu to $n a 74 \%$ to $26 \%$ & $v r z$ to $n a 0.055 \%$ to $99.94 \%$ \\
\hline
\end{tabular}

Table 1 shows the results of a Google search of four direct strings with vrz/vărhu and $n a$. Although the numbers present the raw score, the differences are indicative of the preferences in the two languages. The results lend support to our conclusion that vărhu is far more common in the "spreading" sense than vrz.

If the TR's contact surface is equal or larger than the LM's, the functional component of covering may be interpreted as "protection" or "hiding from view", cf. examples (52) and (53), causing the creation of an implicature of layering. This use of both vrz and vărhu is common in culinary discourse to convey layering in a horizontal structure, illustrated in examples (54) and (55).

(52) Toj nosi košula vrz bluzata. (M)

'He is wearing a shirt over his long-sleeve T-shirt.'

(53) Toj be obljakăl palto vărhu pulovera. (B)

'He had put on a jacket over his pullover.'

(54) Rezanki od kruškite se stavaat vrz sloj od karamela i se pokrivaat so sloj na meko testo. (M)

'Slices of pear are placed on the layer of caramel and are covered with a layer of soft pastry.'

(55) V tava izsipete solta, sled koeto vărhu neja naredete pileškite butčeta. (B) 'Cover the pan with a layer of salt and place the chicken legs in a row over it.' 
Placing the same type of TR one over another (56) produces a special effect that results in the conventionalization of the implicature of layering. This functional meaning makes the construction liable to idiomatization, such as edin vărhu drug in (57). In Bulgarian, the colloquial (obsolete) preposition vrăz is often used for expressivity in some idiomatic expressions; for instance sedi krak vrăz krak 'sit with crossed legs', which has the Macedonian equivalent sedi noga vrz noga.

(56) Sloj vrz sloj pudra izgleda lošo. (M)

'Layer upon layer of powder looks bad.'

(57) Te trupat matraci edin vărhu drug. (B)

'They pile up mattresses one over the other.'

The prepositions preku/po, na, and nad compete with vrz in this function, but they highlight different aspects of the superposition topology. The focus of preku/po falls on the extension of the TR over the entire surface of the LM, underscoring completeness to a higher degree than vrz (compare examples (58) and (59)), whereas the use of na is neutral regarding the scope of spread/coverage (60); nad implies vertical proximity (61).

(58) Nanesuvajte go proizvodot ... preku celata površina. (M)

'Spread the product over the whole surface.'

(59) Koga ke se nanese vrz pluskavicata, pastata za zabi pobrzo ja suši. (M)

'When you smear toothpaste over a blister, the blister dries faster.'

(60) Nanesete eukaliptusovo maslo na krpče i izbrišete. (M)

'Spread eucalyptus oil on a piece of cloth and use for cleaning.'

(61) Nad testoto stavete go filot, a nad nego šlag krem ... (M)

'Spread custard over the pastry and put some whipping cream on top...'

Sometimes the difference between these prepositions is so negligible that they may be used interchangeably to avoid repetition (62). However, note that $v r z$ is used for a smaller object that is on top but does not cover the entire surface of the LM.

(62) Parčinja gorgonzola stavete na sekoe ispečeno lepče, a vrz nea stavete jatka orev. (M)

'Put some gorgonzola on each toasted slice of bread, and over it place half a walnut.'

\section{[2.10] Abstract meaning: recursiveness}

The meaning of recursive activity (paleše cigara vrz cigara 'He lit cigarette after cigarette'; pišuvaše pismo vrz pismo 'she wrote letter after letter') is extended from 
the sense of physical piling or layering of entities one over another. Repetition of the same activity creates an implicature of quantity that has relevance in some particular context (63). In Bulgarian we found the emotionally-marked preposition vrăz in this function (64).

(63) Se trošat narodnite pari, se udira danok vrz danok, ... (M) 'The people's money is spent, tax after tax is imposed,...'

(64) Ot tri godini pismo vrăz pismo mi piše, ela mi na gosti, badžanak. (B) 'For three years he's been writing me letter after letter, come and visit me, brother.'

\section{[2.11] Summary: the network of spatial and abstract meanings of vrz and vărhu}

The semantic network of the prepositions vrz/vărhu is shown on Figure 1. As discussed above, three spatial meanings branch from the meaning 'on top of representing the abstract image schema and each has given rise to one or more abstract meanings.

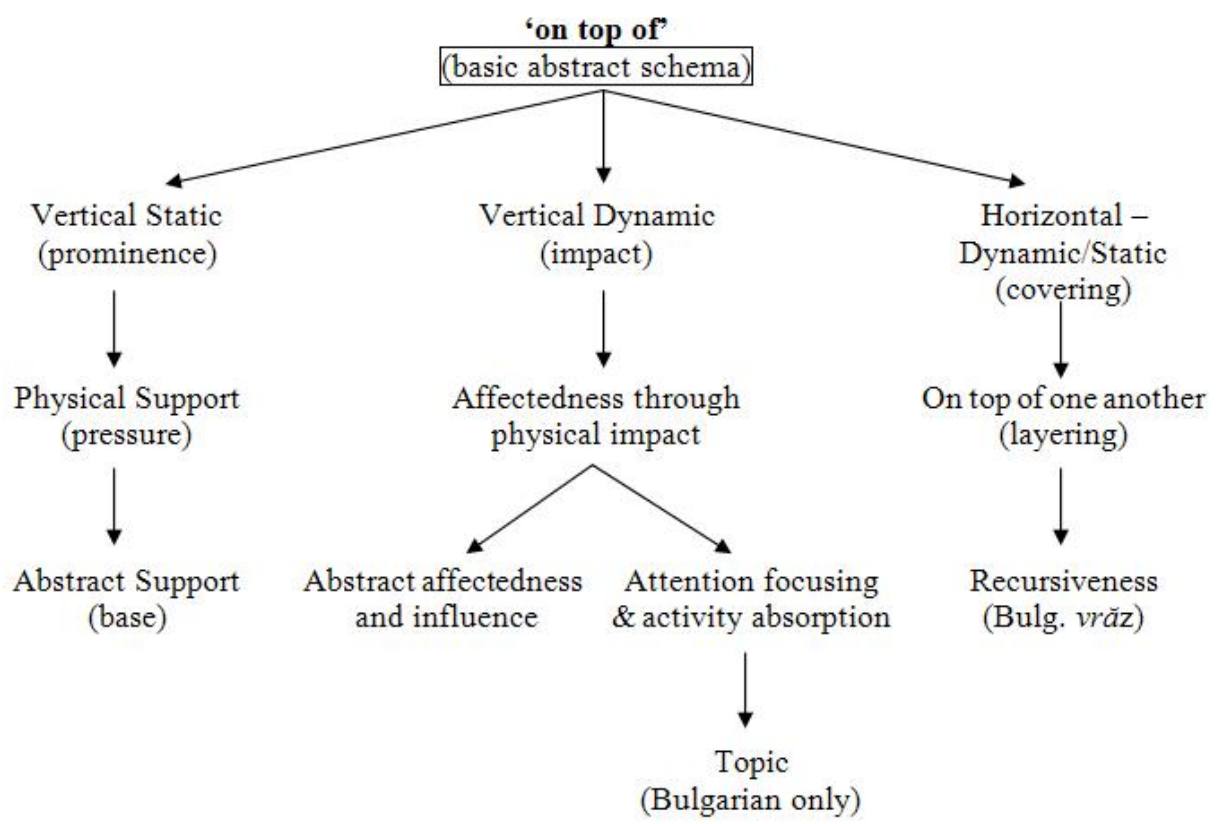

FIGURE 1: The conceptual network of $v r z$ and vărhu

We distinguish between vertical and horizontal types of meaning on the basis of the nature of the contact. In the vertical meanings it is restricted to a relatively small portion of the LM, whereas in the horizontal ones it spreads radially and 
may cover the entire surface. Both orientations are found in static and dynamic patterns. In the vertical orientation, the two patterns are cognitively distinct, which is reflected in the existence of two senses (prominence and impact). This hypothesis is supported by the fact that both senses serve as sources for separate extension pathways: pressure versus affectedness through physical impact. On the other hand, in the horizontal orientation the distinction between the static and dynamic meanings is neutralized in the covering sense with its two contextual variants.

The two varieties of the dynamic pattern may be characterized as a forcedynamic pattern and force-dynamically neutral pattern, the difference being in the orientation of movement: vertical or horizontal. In the force-dynamic pattern, the object comes in contact with the surface as a result of vertical impact ${ }^{18}$ (downward movement). The dynamicity of this conceptualization may be neutralized by the different orientation of the impact. In a force-dynamically neutral pattern the object moves radially, in all directions along a planar surface, which is usually but not necessarily horizontal (pločki vrz dzidot 'tiles over the wall'). In sum, the dynamic meanings analyzed share a similar topological configuration of superpositional attachment, the main difference being in the verticality or horizontality of the attachment relation. Verticality produces the meaning of "contact attachment"; that is, only in the place of impact, whereas horizontality conveys "spreading attachment" on all (or a fair amount of) the surface of the LM. As a consequence, the functional component of affectedness weakens at the expense of the covering component, also conveying certain affectedness itself.

The two vertical varieties (impact and prominence) may be conceptualized as two poles of a force-dynamic continuum with different degrees of affectedness. It is most prominent in the vertical dynamic conceptualization of the relation coded by $v r z / v a ̆ r h u$, which is based on the presupposition of a preceding forceful or neutral movement. The degree of affectedness is lower in the static pattern, which is conceptually simpler because the profiled relation does not trigger the presupposition of movement; that is, the activity that has led to the contact is not in the focal zone of the conceptualization scene. ${ }^{19}$ The preposition profiles the relation of the attached superposition, which contextually determines affectedness. However, the distinction between the two patterns is often blurred. In Ne sedi vrz mojot krevet! 'Don't sit on my bed!' vrz implies some affectedness but the

[18] Compare Lindstromberg's explanation of the English preposition against, which includes the element of force and suggests violent impact (Lindstromberg 1997, 177).

[19] Or in the zone of cognitive "ception." This partly overlaps with what Langacker calls "focal prominence." According to Langacker $(2008,365)$, focal prominence "resides in the directing of attention, made necessary by the difficulty of viewing a complex occurrence in a global and a wholly neutral fashion-we cannot attend to everything equally and simultaneously. As a limited resource, attention has to be allocated and for a given structure different allocations are possible." 
verb itself codes a static situation even though it is obviously a result of a dynamic activity.

Therefore, the three meanings are distinguished by their functional features: prominence, affectedness (impact), and covering, respectively. Each has given rise to a corresponding abstract meaning, with some final branches differing in Macedonian and Bulgarian.

\section{Comparison between vrz and vărhu}

The above overview shows that the Macedonian preposition $v r z$ and its Bulgarian counterpart vărhu are close equivalents used for expressing similar spatial relations of attached superposition. It seems that they have followed similar paths of extension to abstract meanings. However, our analysis has shown that there is difference in usage. It seems that the Bulgarian vărhu is more widely used in the senses of "position on top of," "spread on a surface," and "support," in which the affectedness component is weak. The implication of affectedness is more strongly felt in Macedonian $v r z$, which makes it more expressive and thus less common in contexts lacking affectedness. To draw more specific conclusions, though, a precise statistical analysis of the occurrences of these prepositions in the two languages is needed, but at this point such an analysis is unfeasible because there is no extensive electronic corpus of Macedonian.

We also noted some differences in the scope of abstract meanings:

(i) Bulgarian vărhu is used in some abstract meanings in which Macedonian $v r z$ is not applied: the meaning 'about', expressing topic, was mentioned above (Sporim vărhu tozi problem 'argue over this problem'); second, it has a distributive meaning in expressing percentages (20\% DDS vărhu 1 lev '20\% VAT on 1 lev'), where Macedonian uses na; in mathematics it is used for expressing ratios (deset vărhu petnaeset 'ten divided by fifteen').

(ii) In the abstract meaning of support (se bazira/zasnova $v r z$ ), Macedonian $v r z$ is very common, whereas Bulgarian vărhu is restricted to one verb and na is more usual.

\section{[3] VRZ AND VĂRHU IN RELATION TO SIMILAR PREPOSITIONS ON SUPERPOSITION}

This analysis has revealed the relation of the preposition $v r z / v a ̆ r h u$ to some semantically close prepositions. Our starting premise is that spatial prepositions mark meaning distinctions in a stable conceptual domain and that their meanings are determined in relation to the other prepositions with which they share this domain (Tyler \& Evans 2003, 108). Therefore, on the one hand the meaning of a preposition depends on the scope of similar spatial prepositions and, on the other, on specific functional implications evoked by prepositions that give each of them a characteristic nuance. 
TABLE 2: Component features of the preposition vrz in relation to its similar prepositions

\begin{tabular}{lllll}
\hline & VRZ & NA & PO, PREKU/PREZ & NAD \\
\hline contact & + & + & + & $+/-$ \\
\hline pressure & + & + & & \\
\hline affectedness & + & + & & \\
\hline support & + & + & & \\
\hline spreading & + & & + & + \\
\hline covering & + & & + & + \\
\hline layering & + & & + & + \\
\hline overhanging & + & & &
\end{tabular}

Table 2 shows the specific features characteristic for the prepositions vrz/vărhu, $n a, p r e k u / p r e z, p o$, and nad in the spatial domain expressing a position of a TR on the upper surface of a LM. It is obvious that not all functional components are shared by all prepositions, the contact component being the only common one. Apart from contact, the preposition vrz/vărhu shares with na the components of pressure, affectedness, and support; it is connected to preku/prez, po through spreading, covering, and layering, and to nad through covering, layering, and overhanging.

Such overlap of features indicates that the domains of these prepositions share a common semantic field, which explains their interchangeability in particular contexts. Figure 2 represents the functional domains of $v r z / v a ̆ r h u$ and the competing prepositions. In contexts in which a particular functional component is prominent, the use of $v r z / v a r h u$ is compatible with the preposition that has the same property. However, although these prepositions contain the same features in their semantic structure, each preposition displays a different hierarchy of these features. Usually, the dominant feature of a particular preposition distinguishes it from other semantically close prepositions. Thus the meaning of "attached superposition" of $v r z / v a ̆ r h u$ can also be coded by na, but the features of pressure, affectedness, and support do not have the same significance in both: whereas $v r z / v a r r h u$ underscores pressure and affectedness, the dominant feature for $n a$ is support, cf. examples (39) and (40). In the meaning of "spread over some surface, covering," vrz/vărhu shares a domain with po and preku/prez, but the central feature for the latter is "spreading," whereas for the corresponding meaning of $v r z / v a ̆ r h u$ it is "covering", cf. examples (54) and (55). The same function can be expressed by the preposition nad, but for this preposition "overhanging" (created by the topology of detached superposition) is the central feature (61). 


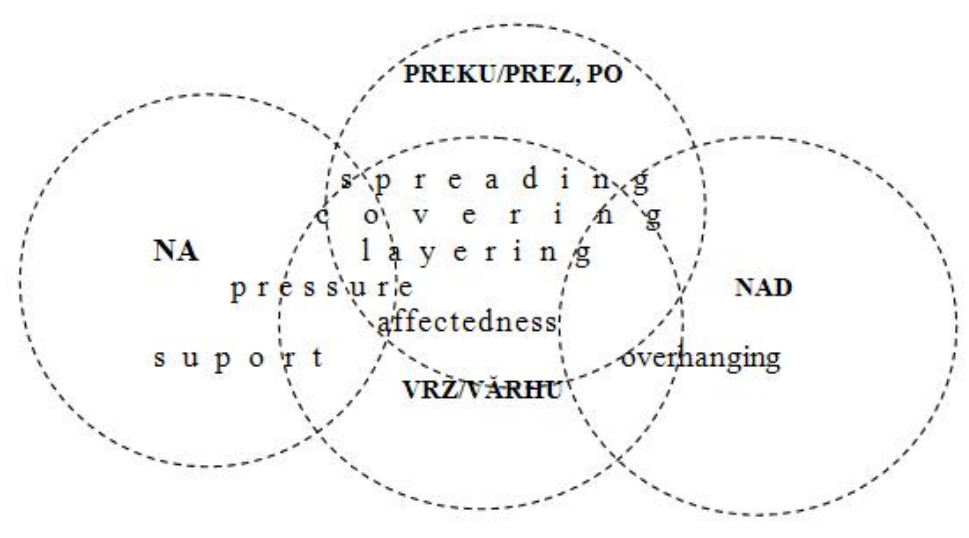

FIGURE 2: The scope of the preposition $v r z$ in relation to similar prepositions

Similar overlaps are typical of non-spatial meanings. Abstract affectedness and/or control over a LM may be expressed by na; compare examples (39)-(43). The functional meaning "overhanging" in $v r z$ that has derived from "focusing" attention (e.g., with the verb raboti 'work') may be coded by nad and na, but vrz implies greater directionality, hence involvement. $V r z / v a ̆ r h u$ shares the functional domain of covering with po, preku/prez, and na, but na does not imply total spreading (all over the surface), as do preku/prez and po. Only vrz/vărhu has developed the "recursiveness" sense derived from "layering."

The meaning of support is more central to spatial na than it is for vrz/vărhu, but $v r z$ is more often used for moral support (se potpiram vrz tebe 'I rely on you' vs. se potpiram na tebe 'I lean on you'). Examples (65)-(67) demonstrate how these prepositions are mutually interchangeable in some contexts, which indicates considerable overlap of their functional zones. Semantic and pragmatic factors such as the nature of participants and the type of activity the participants are involved in determine the choice of the suitable preposition for a particular situation.

(65) Ja staviv knigata na masata. ( ${ }^{*}$ nad, ${ }^{*} v r z,{ }^{*}$ preku) (M)

'I put the book on the table.'

(66) Go rasposlav čaršavot na masata. (*nad, ?vrz, preku) (M)

'I spread the tablecloth on the table.'

(67) Ja staviv rakata na očite. (?nad, vrz, preku) (M)

'I put my hand over my eyes.' 
To support the results presented in our analysis, it would be helpful to conduct a statistical investigation of the relationship of $v r z / v a ̆ r h u$ with other rival prepositions. The comparison of frequency of prepositions in different syntactic constructions should help reveal the factors influencing the choice of a particular preposition. Given that a rigorous statistical analysis was beyond the scope of this article, the findings of our analysis may serve as a foundation for future statistically based investigations.

\section{[4] CONCLUDING REMARKS}

In the above cognitive-based analysis of the prepositions vrz and vărhu, we have established the role of the functional element "affectedness" in the meaning of this spatial category. With the verticality dimension as part of this configuration, the category profiles not only a topological relation of attachment, but implies direction and impact. We adopt the view (held by other authors cited in this article) that spatial relations coded in prepositions are primary and that " $[t]$ he functional element arises as a consequence of our daily interaction with the spatial configuration associated with the particular preposition" (Tyler \& Evans 2004). Thus we assume that affectedness is a byproduct of directional movement in a force-dynamic pattern triggered by the frequent occurrence of these prepositions with a certain type of verbs. Affectedness has become their distinguishing feature, especially in the case of vrz. We argue that this preposition contains a functional component in all senses, which vary from "prominence" through "impact" to "covering." Although "affectedness" prevails in the second sense, which is the most frequent and productive, it is also felt in the other two senses. All of these functional components trigger the creation of numerous extensions in the abstract domain. Furthermore, we have tried to uncover the interaction of the affectedness component and the superposition component in the conceptual structure of these prepositions. The analysis has led to the conclusion that dimensionality and contextual factors influence the prevalence of one or another component and subsequently determine the degree of affectedness.

The analysis has also focused on the polysemy of the prepositions vrz/vărhu. We have determined the meanings of these prepositions by positing the existence of dynamic and static pattern in their configurations, outlined in Section [2.11]. This enabled us to find associative links between different, seemingly unrelated meanings and demonstrate the structural character of the system lexicalized by these prepositions.

Finally, we have conducted two types of contrastive analysis: between the prepositions $v r z$ and vărhu and between $v r z / v a ̆ r h u$ and the other prepositions of attached superposition. Whereas the aim of the first comparison was to delineate the functional zone of $v r z$ versus vărhu, in the second comparison we isolated the 
functional features that set $v r z / v a ̆ r h u$ apart from other semantically close prepositions.

\section{REFERENCES}

Andrejčin, L., L. Georgiev, S. Ilčev, I. Kostov, I. Lekov, S. Stojkov \& C. Todorov. 1963. Bălgarski tălkoven rečnik. Sofia: Nauka i izkustvo.

Beavers, J. 2002. Prepositions in UK Monolingual Learners' Dictionaries: Expanding on Lindstromberg's Problems and Solutions. Applied Linguistics 23(1). 34-140.

Beavers, J. 2011. On Affectedness. Natural Language and Linguistic Theory 29. 335-370.

Brala, M. 2005. Crosslinguistic diversities and cognitive universals in the semantic domain of superposition. In J. Granić (ed.), Semantika prirodnog jezika i metajezik semantike, 89-100. Zagreb: Hrvatsko društvo za primijenjenu lingvistiku.

Coventry, K. R. 1998. Spatial Prepositions, Functional Relations, and Lexical Specifications. In P. Oliver \& K. P. Gapp (eds.), Representation and Processing of Spatial Relations, 247-262. Mahwah, NJ: Lawrence Erlbaum.

Coventry, K. R. 2003. Spatial Prepositions, Spatial Templates and "Semantic" versus "Pragmatic" Visual Representations. In E. Van der Zee \& J. Slack (eds.), Representing Direction in Language and Space, 255-267. Oxford: Oxford University Press.

Coventry, K. R. \& S. C. Garrod. 2004. Saying, Seeing and Acting: The Psychological Semantics of Spatial Prepositions. Hove: Psychology Press.

Dąbrowska, E. 1997. Cognitive Semantics and the Polish Dative. Berlin: Mouton de Gruyter.

Navarro i Ferrando, I. 2001. Is Function Part of the Literal Meaning of English Prepositions? In L. Šarić \& D. F. Reindl (eds.), On Prepositions, 36-62. Oldenburg: Bibliotheks und Informationssystem der Universität Oldenburg.

Janda, L. A. 1993. A Geography of Case Semantics: The Czech Dative and the Russian Instrumental. Berlin: Mouton de Gruyter.

Johnson, M. 1987. The Body in the Mind: The Bodily Basis of Meaning, Imagination and Reason. Chicago: University of Chicago Press.

Koneski, K. (ed.). 2003. Tolkoven rečnik na makedonskiot jazik, vol. 2. Skopje: IMJ. 
Langacker, R. W. 2008. Cognitive Grammar: A Basic Introduction. Oxford: Oxford University Press.

Lindstromberg, S. 1997. English Prepositions Explained. Amsterdam: John Benjamins.

Mitkovska, L. 2007. Why Double Marking in the Macedonian Dativus Sympatheticus. In D. Divjak \& A. Kochańska (eds.), Cognitive Paths into the Slavic Domain, 55-79. Berlin: Mouton de Gruyter.

Mitkovska, L. \& E. Bužarovska. 2012. The Preposition and Prefix Nad in South Slavic with Emphasis on Macedonian. Jezikoslovlje 13(1). 107-150.

Murgoski, Z. 2005. Rečnik na makedonskiot jazik. Skopje: Murgoski.

Pašov, P. 2002. Bălgarska gramatika. Plovdiv: Hermes.

Šarić, L. 2008. Spatial Concepts in Slavic. A Cognitive Linguistic Study of Prepositions and Cases. Wiesbaden: Harrassowitz.

Skok, P. 1973. Etimologijski rječnik hrvatskoga ili srpskoga jezika. Knjiga treća. Zagreb: JAZU.

Talmy, L. 2000. Towards a Cognitive Semantics II: Typology and Process in Concept Structuring. Cambridge, MA: MIT Press.

Taylor, J. R. 2002. Cognitive Grammar. Oxford: Oxford University Press.

Tyler, A. \& V. Evans. 2001. Recognizing Prepositional Polysemy Networks: The Case of Over. Language 77(4). 724-776.

Tyler, A. \& V. Evans. 2003. The Semantics of English Prepositions: Spatial Scenes, Embodied Meaning and Cognition. Cambridge: Cambridge University Press.

Tyler, A. \& V. Evans. 2004. Rethinking English "Prepositions of Movement": The Case of To and Through. Belgian Journal of Linguistics 18(1). 247-270.

Van Valin, R. D. Jr. 2002. Semantic Macroroles in Role and Reference Grammar. http://linguistics.buffalo.edu/people/faculty/vanvalin/ rrg.html. 
AUTHOR CONTACT INFORMATION

Eleni Bužarovska

Ss. Cyril and Methodius University

Blaže Koneski Faculty of Philology

Bul. Goce Delčev bb, 1000 Skopje

Republic of Macedonia

elenibuzarovska@t-home.mk

AUTHOR CONTACT INFORMATION

Liljana Mitkovska

FON University, Skopje

Faculty of Foreign Languages

Bul. Vojvodina br. 51000 Skopje

Republic of Macedonia

liljana.mitkovska@fon.edu.mk 